\section{Miscellaneous}

\section{Ubaldo Cuesta Cambra}

https://orcid.org/0000-0001-7023-7132 ucuestac@ucm.es

Universidad Complutense de Madrid

José Ignacio Niño González

https://orcid.org/0000-0003-2775-7241 josenino@ucm.es

Universidad Complutense de Madrid

Giorgio De-Marchis

https://orcid.org/0000-0001-9217-3141 giorgiodemarchis@ucm.es

Universidad Complutense de Madrid

\section{Submitted}

October 18th, 2019

Approved

September 7th, 2020

\section{(C) 2021}

Communication \& Society

ISSN 0214-0039

E ISSN 2386-7876

doi: 10.15581/003.34.2.15-29

www.communication-society.com

$2021-$ Vol. 34(2)

pp. $15-29$

\section{How to cite this article:}

Cuesta Cambra, U., Niño González,

J. I. \& De-Marchis, G. (2021). Uses and gratifications of multiscreen news consumption among Spanish youth. Communication \& Society, 34(2), 15-29.

\title{
Uses and gratifications of multiscreen news consumption among Spanish youth
}

\section{Abstract}

This paper aims to describe how Spanish youth use multiscreen in a news search context, and what are the gratifications they obtain through this multichannel model. A survey was responded by a panel of 441 individuals representative of the national population in an 18-35 age range. Five gratifications were found: the desire to obtain "information in real time," "social interaction," "comprehension," "leisure," and "habit." The desire to obtain "information in real time" predicts multiscreen use behavior when searching for news. Moreover, three factors are relevant when predicting the duration of multiscreen use: "information in real time," "social interaction," and "leisure."

Keywords
Multiscreen, multitask, news, uses and gratifications.

\section{Uses and gratifications of multiscreen news consumption among Spanish youth}

Technological advances and new intermediation and interactivity tools, such as the Internet, social networks and mobile communications have transformed the current media space (Rainie \& Wellman, 2012). Today's fast, segmented, convergent and interconnected information is prioritized (Pedreira \& de Casas Moreno, 2016). In the framework of this new communicational universe, the recipient is called "user" (Sundar \& Limperos, 2013) and has shifted from a stage where information was consumed in a standardized manner to another where users decide where and when to consume media, how to interact with them (e.g., comments), or even how to produce them (e.g., Periscope). The linear consumption of media by users has experienced a deep change driven by an underlying growth in mobile devices and other reception platforms. Individuals show a high degree of dependence on these devices that can lead to behavioural modifications and to some extent influence their quality of life (Niño \& Fernández, 2015). Audiences no longer interact with comunication media through a single medium, but instead access them from different devices (Fernández, 2013; Diego, Guerrero \& Etayo, 2014). These audiences are made up of a typology of individuals that are increasingly "more demanding, prefering quality content that they access where and when they want" (Yuste, 2015). The existence of a wide offer of electronic communications devices has promoted the emergence of what is now termed "media multitasking" (Wang \& Tchernev, 2012). For the existence of multitasking, an individual must be involved in two or more activities at the same time in a cognitive or behavioral manner. Cooking and listening to the radio are an example of media multitasking, because it is enough that one of the two 
tasks is related to media, radio in this case. Multitasking might be sequential or simultaneous depending on the time used between tasks (Salvucci, Taatgen \& Borst, 2009). For Chun, Lee and Kim (2012), in this duality of tasks, attention is distributed among occupations in a dynamic and interactive manner. The increase of multitasking occurs mainly among youth while listening to music, watching television, using the computer or reading (Rideout, Foehr $\&$ Roberts, 2010) being the combination of television and mobile most frequent amongst this age group (Giglietto, 2014; Dias, 2016).

The reason for starting this research is to understand and document the motivations that drive multiscreen usage in its relevance to the ways citizens currently consume news. We intend to do this by running a descriptive study.

\section{Uses and Gratifications Theory}

For decades, researchers have analyzed the behavior and motivation of traditional media usage. The 'Uses and Gratifications Theory' (U\&G) aims to understand what an audience does with media and why. The first U\&G studies started back in the thirties of the past century and were focused on the effect of media on an audience considered passive before exposure to said media coverage. It was supposed that the public had information "injected" as suggested by Lasswell's (1948) hypodermic needle theory. This paradigm was transformed by Katz (1959) studies, when the audience started to be considered as an active element driven by needs (Rubin, 2009). By progression, a new model of uses and gratifications was suggested, whereby the public behaves in an active manner because it is motivated. Therefore, mass media consumption is understood by its capacity to satisfy individuals' needs in a specific social context (Katz, Blumler \& Gurevitch, 1973; McQuail, 1979). According to McQuail, Blumer and Brown (1972), the audience gets amusement from media (escape from routine and emotional liberation), personal identity (personal reference), and environment's surveillance (information and learning). For Katz, Gurevitch and Hass (1973) the use of media covers four main categories of needs: cognitive (to keep informed), affective or evasive (to relax or be entertained), of personal integration (self-knowledge) and social (to strengthen family or friends' bonds).

In a parallel manner to recent technological developments, the U\&G theory has been focusing on the study of media, Internet and social networks (LaRose \& Eastin, 2004; Rubin, 2009), finding specific gratifications therein such as entertainment and comfort (Papacharissi and Rubin, 2000), search for information, interactivity (Korgoankar \& Wolin, 1999), problem resolution, maintenance of relationships with others and the search for status (Flanagin \& Metzger, 2001; Charney \& Greenberg, 2001). On the other hand, Leung (2009) suggests four gratifications that drive online content generation and are linked to the needs of acknowledgment, comprehension, social interests and entertainment.

The application of U\&G also approaches specifically the use of the mobile phone as a device with strong media delivery capacities. Leung and Wei (2000) identified some gratifications that existed in traditional telephones, such as social interaction and the expression of affection, that widen with the generalized use of mobile telephones adding new dimensions not present in fix line communication. Specifically, this mobile usage adds factors such as relaxation when referring to online "chatting" and other social pass-times enhanced by the possibility to communicate immediately, at any time and almost any location. There is also a certain demonstration of status or fashion exhibited by the individual when he or she owns a specific phone model. Mobile devices can access the Internet to find information, recommend, generate and distribute content and are increasingly being used to inform consumer choices (Álvarez, de Haro \& Picard, 2018). Hence, these mobile devices offer greater accessibility, information exchange and social interaction and in general generate a more intense usage pattern, a greater consumption of published material and a higher frequency of content publication (Cheng, Liang \& Leung, 2015). 


\subsection{Literature review on effects of multitasking}

Different works demonstrated that performing several tasks simultaneously impact cognitive performance, as it applies to reading comprehension and memory (Armstrong, Boiarsky \& Mares, 1993), the process of information verification (Gilbert, Tafarodi \& Malone, 1993) and reduce cognitive efficiency (Rosen, Lim, Carrier \& Cheever, 2008; Hembrooke \& Gay, 2003). Research on multitasking by Jeong and Hwang (2016) evidenced that performing several tasks simultaneously related to media causes some negative effects on results (i.e., less efficiency) but positive effects on persuasion (i.e., greater persuasion since information is processed more superficially). In the same line of the previous research, Dindar and Akbulut (2015), in their study about multitasking effects, compared a group of participants that viewed several videos versus another group that viewed the same videos while answering an online chat. Data showed that the group under multitasking conditions took a longer time to process information, but the final result evidenced the same level of comprehension in both groups. On the other hand, the negative effects appear moderated by the control the user has on media he interacts with (i.e., with the traditional television there is a low control since it cannot be paused), by the task's relevance, and by the relationship between tasks performed. In any case, beyond positive or negative aspects, the multitasking process is always gratifying when emotional needs with low cognitive burden are involved, like entertaining or relaxing (Wang \& Tchernev, 2012).

The motivations for multitasking are multiple and varied. The Ingunn and Rice study (2007) explains that motivations leading to perform multitasking are based on three main aspects: first, it requires doing multiple activities simultaneously with the subsequent time optimization, second, it fights boredom, and third, calms impatience since it is possible to manage several things at the same time. Accordingly, smartphone users perform multitask for efficiency, feeling positive sensations and usefulness (Lim \& Shim, 2016).

\subsection{Literature review on effects of multiscreening}

Although there are multiple situations that can be identified as multitasking, there is a typology with its own characteristic features known as multiscreen on which we focus in this paper. This modality can be defined as the use of more than one screen in a simultaneous and combined manner: it may include the computer for working, the television to get informed, mobile phones to be connected with other people, and tablets for entertainment (Lin, 2013; Giglietto \& Selva, 2014). For users, the reasons for using multiscreen lie in better time management due to performing simultaneous activities, mostly through the mobile phone (Dias, 2016). In the multiscreen case using two screens, studies like those of Choi, Kim, and McMillan (2009) find similar gratifications to those of other media such as access to information, communication, leasure time, entertainment, social interaction, fashion and status.

An even more specific multiscreen formula occurs when at least one of the two screens contains a source of information. In the current context of information excess, individuals have a wide range of formats available, and we are aware they use a multiplicity of platforms to satisfy their informative needs. We are facing an audience that migrates from one media to another looking for information (Lin \& Cho, 2010), for instance looking at Internet data about a news story they have seen previously on television, commenting on the mobile phone about a program they are watching, browsing a website or looking for more detailed information about newspapers articles (Shade, Kornfield \& Oliver, 2015).

\subsection{Literature review on the effects of a second screen}

Findings reveal that young people tend to second screen more than older counterparts. Similarly, there are also differences in political behaviours between groups of high and low frequency second screen users. More intensive users tend to politically express 
themselves in social media, and participate more often in offline political activities (Gil de Zúñiga \& Liu, 2017).

There are multiple works focused on informational uses and consumption of young Spaniards (Flores \& Humanes, 2014; Quan-Haase \& Young, 2010) and although there are not too many studies providing knowledge about the use of several simultaneous screens in a context of media consumption of news, we can highlight research such as that carried out by Vaccari and Valeriani (2018) who determine that watching news with political content on television while reading and commenting on social networks generates a favorable predisposition for the participation of citizens in politics. In this line, the objective of this paper is to contribute with knowledge in this field. Therefore, we decided to conduct a descriptive study whose research questions are how and why multiscreen with news is used. The study of these questions will help us understand the nature of the phenomenon and offer a basis on which generate experimental research (Levitin, 1999).

\section{Method}

\subsection{Procedure}

We decided to use a descriptive research design where we combined qualitative and quantitative techniques (Cook \& Reichardt, 1986). Since there is no previous specific research about multiscreen use with news, we needed to perform exploratory work that could capture the different perceptions as much as possible.

Data collection was structured as follows: a first phase in which two discussion groups were carried out, whose responses, together with a review of the published literature, helped us develop a questionnaire. In a second phase, a questionnaire was conducted on a panel of 300 participants who provided us with the data to obtain a description of the reality presented through descriptive results, mean analysis, factor analysis, and regression analysis.

\subsection{Sample}

Each one of the two focus groups was formed by 10 participants ranging from 18 to 35 years old where we established, as condition, that there was a balance of $50 \%$ between men and women and average socioeconomic class.

To obtain the sample, a random recruitment was carried out among subjects from the population of Madrid who met the aforementioned filters.

In a second quantitative stage (Table 1 ) we hired a company that provided a panel of 300 individuals selected so that the sample could be as representative of the Spanish population as possible. About sample selection, we considered the variables of gender, age (between 18 and 35 years old), socioeconomic class and geographical distribution (i.e., Spanish regions). The questionnaire was carried out through an online application. An average time of 15 minutes was established to complete it. 
Table 1: Sample distribution.

\begin{tabular}{|c|c|c|c|}
\hline & & Frequency & Percentage \\
\hline \multirow{2}{*}{ Gender } & Male & 178 & 40.4 \\
\hline & Female & 263 & 59.6 \\
\hline \multirow{2}{*}{ Age } & $18-24$ & 252 & 57.1 \\
\hline & $25-35$ & 189 & 42.9 \\
\hline \multirow{5}{*}{$\begin{array}{l}\text { Geographic } \\
\text { distribution }\end{array}$} & North & 139 & 31.5 \\
\hline & Center & 148 & 33.6 \\
\hline & West & 66 & 15.0 \\
\hline & East & 22 & 5.0 \\
\hline & South & 66 & 15.0 \\
\hline \multirow{7}{*}{$\begin{array}{l}\text { Completed } \\
\text { studies }\end{array}$} & No official degree, incomplete studies & 6 & 1.4 \\
\hline & $\begin{array}{l}\text { School graduate or Compulsory Secondary } \\
\text { Education }\end{array}$ & 32 & 7.3 \\
\hline & High school & 167 & 37.9 \\
\hline & Degree of Professional Training & 102 & 23.1 \\
\hline & Graduate or Bachelor & 91 & 20.6 \\
\hline & Master's degree besides Graduate or Bachelor & 39 & 8.8 \\
\hline & Doctorate & 4 & .9 \\
\hline \multirow{6}{*}{$\begin{array}{l}\text { Main activity } \\
\text { currently* }\end{array}$} & Study & 193 & 43.8 \\
\hline & Work as intern after completing studies & 3 & .7 \\
\hline & Part time job & 34 & 7.7 \\
\hline & Full time job & 97 & 22.0 \\
\hline & Active job search & 30 & 6.8 \\
\hline & Not answered & 84 & 19.0 \\
\hline
\end{tabular}

* $\overline{\text { Main activity was defined as the activity the respondent dedicates a greater number of hours per day. }}$ Source: Own elaboration.

\subsection{Materials}

A questionnaire was developed with the double objective of identifying the factors related to the uses of multiscreen and the gratifications obtained thereof. Items were adapted from papers where the use and gratifications in mobiles and multiscreen were studied (Dias, 2016; Choi et al., 2009; Grellhesl \& Punyanunt-Carter, 2011; Bolton et al., 2013). Questions were structured in a 5-point Likert scale, where 1 was the minimum value and 5 the highest value.

\section{Results and Discussion}

Firstly, we present our results about uses; secondly, we will present our results about gratifications.

Table 2 shows descriptive data of the use of two screens when there are news in one of them. 
Table 2: News consumption.

\begin{tabular}{|l|c|c|c|c|c|}
\multicolumn{2}{l}{ N N Mean } & Median & Mode $\begin{array}{l}\text { Standard } \\
\text { deviation }\end{array}$ \\
\hline $\begin{array}{l}\text { Interest in news and what happens in Spain and the } \\
\text { world }\end{array}$ & 441 & 4.3 & 4.0 & 4 & .7 \\
\hline Frequency of use of mobile phone to get informed & 441 & 4.3 & 5.0 & 5 & .9 \\
\hline Frequency of use of radio to get informed & 441 & 2.3 & 2.0 & 2 & 1.1 \\
\hline $\begin{array}{l}\text { Frequency of use of printed journals/magazines to get } \\
\text { informed }\end{array}$ & 441 & 2.1 & 2.0 & 2 & .9 \\
\hline Frequency of use of printed newspapers to get informed & 441 & 2.3 & 2.0 & 2 & 1.0 \\
\hline Frequency of use of PC to get informed & 441 & 2.6 & 2.0 & 1 & 1.4 \\
\hline Frequency of use of laptop to get informed & 441 & 3.7 & 4.0 & 4 & 1.2 \\
\hline Frequency of use of tablet to get informed & 441 & 2.3 & 2.0 & 1 & 1.3 \\
\hline Frequency of use of television to get informed & 300 & 3.9 & 4.0 & 4 & .9 \\
\hline Days of news consumption per week & 441 & 2.3 & 3.0 & 3 & .8 \\
\hline Daily time used for multiscreen (estimated)* & 441 & 278.2 & 240.0 & 180.0 & 163.9 \\
\hline Time used for multiscreen yesterday (estimated)* & 439 & 231.4 & 180.0 & 120.0 & 172.0 \\
\hline Time used yesterday to consume news & 441 & 125.8 & 120.0 & 120.0 & 109.8 \\
\hline
\end{tabular}

* In minutes.

Source: Own elaboration.

Data collected in Table 2 shows how there is a high level of interest to be well informed in all age ranges, genders and zones, considering that the standard deviation is low. This need is mainly solved through the use of mobile phones, also with a low standard deviation. Television is still the second source, followed closely by laptop, but with a slightly higher standard deviation. As a particularly relevant data we observe the high level of time dedicated to multiscreen, estimated in 278.2 minutes daily. It is surprising that half of the time dedicated to multiscreen the previous day is dedicated to consuming news.

With the following contingence table (Table 3) we want to understand what the most frequent activity is while watching news in a device. 
Table 3: Most frequent activity while watching news in a specific device.

\begin{tabular}{|c|c|c|c|c|c|c|c|c|}
\hline & $\begin{array}{l}\text { Watch } \\
\text { news in } \\
\text { TV on } \\
\text { demand }\end{array}$ & $\begin{array}{l}\text { Read } \\
\text { news } \\
\text { in } \\
\text { emails }\end{array}$ & $\begin{array}{l}\text { Read news } \\
\text { in online } \\
\text { newspapers }\end{array}$ & $\begin{array}{l}\text { Watch } \\
\text { new } \\
\text { son } \\
\text { the } \\
\text { TV } \\
\end{array}$ & $\begin{array}{l}\text { Watch or } \\
\text { read news } \\
\text { "wherever } \\
\text { Google } \\
\text { takes me" }\end{array}$ & $\begin{array}{l}\text { Watch } \\
\text { or read } \\
\text { news in } \\
\text { Tablet }\end{array}$ & $\begin{array}{l}\text { Watch } \\
\text { or read } \\
\text { news in } \\
\text { PC }\end{array}$ & $\begin{array}{l}\text { Watch or } \\
\text { read news } \\
\text { in the } \\
\text { mobile } \\
\text { phone }\end{array}$ \\
\hline Watch the TV & 8.8 & 22.9 & 18.4 & 7.7 & 23.1 & 21.8 & 18.8 & 33.3 \\
\hline Surf Internet & 17.5 & 15.2 & 16.1 & 17.0 & 17.7 & 10.0 & 15.6 & 9.8 \\
\hline $\begin{array}{l}\text { Use social } \\
\text { networks (i.e., } \\
\text { Facebook) }\end{array}$ & 19.0 & 11.3 & 15.6 & 24.0 & 10.4 & 10.4 & 13.8 & 14.1 \\
\hline $\begin{array}{l}\text { Use instant } \\
\text { messaging (i.e., } \\
\text { WhatsApp) }\end{array}$ & 27.9 & 17.5 & 22.9 & 36.3 & 18.1 & 15.2 & 26.5 & 20.0 \\
\hline Read an eBook & .7 & 1.1 & .9 & 1.4 & 1.4 & 1.6 & 1.4 & 1.6 \\
\hline Online chat & 5.2 & 2.3 & 4.5 & 5.2 & 3.2 & 2.3 & 4.1 & 2.7 \\
\hline Study in the PC & 1.6 & 3.9 & 2.7 & .7 & 1.1 & 2.0 & 4.1 & 2.5 \\
\hline $\begin{array}{l}\text { Watch a series } \\
\text { or movie on TV }\end{array}$ & 1.6 & 8.2 & 4.5 & 1.1 & 8.2 & 5.2 & 5.4 & 8.2 \\
\hline $\begin{array}{l}\text { Do not perform } \\
\text { any of these } \\
\text { combinations }\end{array}$ & 17.7 & 17.7 & 14.3 & 6.6 & 16.8 & 31.5 & 10.2 & 7.9 \\
\hline Total & 100.0 & 100.0 & 100.0 & 100.0 & 100.0 & 100.0 & 100.0 & 100.0 \\
\hline
\end{tabular}

\section{Source: Own elaboration.}

It seems that the use of instant messaging applications (i.e., WhatsApp) or browsing through social profiles are the activities combined most with the simultaneous viewing of news on television. The interaction with instant messaging applications combined with the news consumption in PG is also one of the main activities developed as multiscreen. On the other hand, the low consumption of news in a parallel manner with activities such as watching movies or series, study, or read electronic books is worth mentioning.

Next, we analyzed whether there are differences between conditions regarding the multiscreen use (without specifically referring to use together with news). Data obtained indicate that there are no significant differences regarding variables of gender, nor regarding the general estimated use in minutes $[\mathrm{F}(1,439)=.70, \mathrm{p}>.05]$, nor regarding the use the previous day to the questionnaire $[\mathrm{F}(1,437)=3.70, \mathrm{p}=.05]$. Regarding age, results are not conclusive since there are differences compared to the estimated minutes of general use [F(17, $423)=1.90, \mathrm{p}=, 02]$, but there are no differences when we ask about use the day before $[\mathrm{F}(17$, $421)=1.6, p>.05]$. Afterwards, we compared whether there are differences in the use of multiscreen between unemployed individuals and those working full time. There were no differences regarding general evaluation $[\mathrm{t}(125)=.27, \mathrm{p}>.05]$, and neither the evaluation of the day before $[\mathrm{t}(125)=-.10, \mathrm{p}>.05]$. In the case studies completed, there are differences both in general evaluation $[\mathrm{F}(6,434)=5.30, \mathrm{p}<.001]$ as well as in the evaluation the previous day $[\mathrm{F}(6,432)=5.20, \mathrm{p}<.001]$. A post-hoc analysis indicates that differences come from university students whose use differs compared to the other groups. However, this difference can be due to the fact of using a convenience group of university students. On the other hand, studies completed do not seem to be a conclusive characteristic considering that, for instance, there are no differences between individuals without completed studies and individuals with a 
Master's degree, neither in the case of the general evaluation [t(43) $=-1.21, p>.05]$ nor in the case of the evaluation the previous day $[\mathrm{t}(43)=.31, \mathrm{p}>.05]$.

Once the main results related to uses were analyzed, we studied gratifications obtained when there is multiscreen with two devices and in one of them news are consumed. We performed a principal axis factor analysis with Varimax rotation to determine what factors represent the reasons why there is use of multiscreen with news. We indicate the statistical program to show only the factor contributing higher than 3.9. Then, seven (7) factors appear. Five variables that have demonstrated to be useful in the research of gratifications in multiscreen use (Dias, 2016), do not contribute in any factor, and are eliminated ["I believe that an individual who uses several screens to look for news is a person with high capacities to do several tasks at the same time," "It is more comfortable looking for news in two screens than just one," "If I am with my friends and do multiscreen (for instance, television and mobile), I do not tend to look for news," "Using a second screen to comment news or voting is a way to express the way I am," "Audiovisual news are more impactful. With the use of multiscreen I often look for or avoid audiovisual news "].

Considering the last factor is comprised by a single variable ("I consider that an individual who uses several screens to contrast news is a non-conformist), it is eliminated. The use of news with several screens does not seem to be attributed or identified with a way to be. The two variables included in the sixth factor ("With the mobile I know about news my friends select, while in another screen there is a movie or another program," "One of my favorites ways of entertainment is to look at social networks while in another screen there is a movie, a series or any other content") contribute simultaneously and with similar weight to the first factor, and therefore, they are eliminated. The factor analysis is repeated. The 26 variables are distributed into five factors presented on Table 4.

Table 4: Matrix of rotated components.

\begin{tabular}{lllll}
\hline & 1 & 2 & 3 & 5 \\
\hline $\begin{array}{l}\text { If I watch a news story, I am not sure about } \\
\text { (for instance, a very relevant political }\end{array}$ \\
$\begin{array}{l}\text { event), I look on Internet or social networks } \\
\text { in another screen }\end{array}$
\end{tabular}


In general, I know about news my friends post on social networks, and then I tend to look for further information in another

screen

Using several screens at the same time is the best way to be constantly connected to what is happening

I look for information about news in several screens to have other points of view .684 different from the editorial line

Multiscreen with news allows me to contrast (that is, to verify) several .604 informative contents at the same time I always use multiscreen for the monitoring of very impactful news, for instance an .546 earthquake of great intensity

Multiscreen with news makes me feel more connected compared to using only a single screen

Multiscreen with news is a comfortable way of getting several informative contents at the same time

I usually use a second screen to look for comments that confirm my beliefs

I usually multiscreen with news to look for summarized or more comfortable information sources, such as television, to avoid reading complete articles

While I am with news in a screen, I like to interact on social networks to generate interaction with the world in general (that is, not only with my friends)

I entertain myself by commenting news in several screens at the same time: social networks, WhatsApp, etc.

While I am with news in a screen, I like to interact on social networks with my friend's circle

\begin{tabular}{lc}
\hline $\begin{array}{l}\text { Watching news in a screen and to share it in } \\
\text { another one is part of the way I am }\end{array}$ & .485 \\
\hline $\begin{array}{l}\text { I read or watch news in several screens to } \\
\text { relax }\end{array}$ & .719 .690 \\
\hline $\begin{array}{l}\text { I read or watch news in several screens to } \\
\text { get out of routine }\end{array}$ & .477 \\
\hline $\begin{array}{l}\text { I relax by watching news while in another } \\
\text { screen there is a movie or another program }\end{array}$ & .691 \\
\hline $\begin{array}{l}\text { I usually use a main screen for any task, and } \\
\text { another secondary one with news as if it } \\
\text { were a radio, as background noise }\end{array}$ & .634 \\
\hline $\begin{array}{l}\text { I usually use a main screen to watch news, } \\
\text { and another secondary screen as if it were a } \\
\text { radio, or background noise }\end{array}$ & \\
\hline
\end{tabular}

Source: Own elaboration.

The 5 factors explain $47.8 \%$ of variance, with a good reliability (Cronbach Alpha, $\alpha=.88$ ). Factor 1 explains $20 \%$ (Cronbach Alpha, $\alpha=.91)$; and factor 2 explains $11 \%(\alpha=.79)$. Factor 1 corresponds to the profile of "information in real time" with statements such as "If I see a news story, and it is interesting, I look simultaneously on Internet to get more information" 
or "I like to be able to widen news in other media, anytime, anywhere." Factor 2 corresponds with the profile "comprehension of reality" with items such as "I look for information about news in several screens to have other points of view different from the editorial line" or "Multiscreen with news allows me to contrast (that is, to verify) several informative contents at the same time." The rest of factors correspond to profiles such as "social interaction" (6.4\%, $\alpha=.76$ ) with verbatims like "I entertain myself by commenting news in several screens at the same time: social networks, WhatsApp, etc." or "While I am with news in a screen, I like to interact on social networks to generate interaction with the world in general," "leisure" (6.1\%, $\alpha=.7)$ with statements such as "I read or watch news in several screens to relax," or "habit" $(4.2 \%, \alpha=.67)$ with expressions like "I usually use a main screen for any task, and another secondary one with news as if it were a radio, as background noise.” These factors are similar to the ones found by Choi, Kim and McMillan (2009) regarding multiscreen use. Thus, our factor "information in real time," would be "information," our factor "comprehension of reality" could simply be "communication," "social interaction" is the same, "leisure" would be "entertainment," and "habit" would be "spending time." The missing factors in multiscreen with news are "fashion" and "status."

Next, we perform a regression analysis to confirm to what extent factors found are able to predict how many minutes news were consumed the previous day before questionnaire. To carry out said analysis we used the five factors as independent variables. We observed there is a significative linear relationship $[\mathrm{F}(5,435)=17.15, \mathrm{p}<.001]$, however $\mathrm{R}^{2}$ is rather small $\left[\mathrm{R}^{2}=.17\right.$; adjusted $\left.\mathrm{R}^{2}=.16\right]$, having a low predictive capacity. We must consider that respondents referred to the use of news in general, and not the consumption of news while on multiscreen. We avoided the question of how much time they estimated to use multiscreen related to news because it seems a rather complicated estimation to establish. Only the first factor contributes significantly to the model adjustment $[p<0.001]$, while the rest of factors do not have a linear relationship with the dependent variable ( $p>.05$ in the four cases), and therefore they should be excluded from the model. Beta value is 0.33 for factor 1 . These results indicate that, among factors found, only those of looking for "instant and connected information" predict the intensity of news consumption in the evaluation about the previous day.

Afterwards, we repeated the procedure using multiscreen minutes use the day before the questionnaire as the dependent variable. There is a significant linear relationship between the straight line and data $[\mathrm{F}(5,433)=11.03, \mathrm{p}<.001]$, with $\mathrm{R}^{2}=, 11\left(\right.$ adjusted $\left.\mathrm{R}^{2}=.10\right)$ and three factors with predictive capacity, factor $1(\mathrm{p}<.001)$, factor $3(\mathrm{p}<.05)$ and factor $4(\mathrm{p}<.05)$. Respectively, they have a standardized beta of $0.25,0.18$ and -0.12. Factors 2 and 5 do not belong to the model $(\mathrm{p}>.05)$. These results indicate that factors "information in real time," "social interaction" and "leisure" are relevant when it comes to predict the time of multiscreen use.

\section{Conclusions}

There does not seem to be any differences in the use of multiscreen in general between the different genders, age groups or study levels. Therefore, it seems that multiscreen -and as a consequence, multitasking- is a general trend. Data found allow us to state that Spanish youth have a systematic multiscreen behavior as the 278 daily minutes of use demonstrate, from which half of them are destined to looking for news. To consume news means to be informed about what happens in the environment through media. And this represents having a certain mastering or surveillance of the environment (McQuail, Blumer \& Brown, 1972). Therefore, it is an adaptive behavior that enables increasing our safety. Thus, the high level of interest for news in all age ranges, genders and zones, is not surprising, with a very small standard deviation, as well as the fact that half the time used for multiscreen is for consuming new. 
Regarding devices, the mobile is the preferred source to receive information, together with television and computer. Mobility is, most likely, one of the characteristics of media that have a generalized multiscreen use. People can carry along, both at home as well as outdoors, different devices that they end up using simultaneously due to the multitasking behavior trend.

Based on results, we can say that the use of several screens to relate to news does not seem to be attributable or identifiable with a particular way of life, but instead this use is framed within a "natural" consumption pattern in the population segment studied. Television is still an important appliance at home, possibly because it is usually in the living room or bedroom, places where one spends many hours. Consequently, it is easy to use it as second screen or background noise while performing other tasks. In the case of news, we have found that in this simultaneous consumption pattern of screens, television is used to watch news, while the second screen, either computer or mobile phone, is mainly used to interact with instant messaging applications or to surf social networks. Social networks and messaging have a widespread use and are present at all times demonstrating the relevance of social integration for human beings. Therefore, it is not surprising that this social behavior occurs when news content is consumed. Future studies should analyze the way users consume television or other devices as main or secondary media, putting special interest in the new formulas of on demand television consumption that enable a greater control of content by users, and that make it possible to watch or stop news whenever they want. It would also be interesting to study what are the types of news that invite users to comment them in a second screen with other people of their social networks.

The use of several media simultaneously leads to a cognitive deficit, as demonstrated in previous studies. In a way, individuals compensate a task of high cognitive burden with another one of lesser burden. Therefore, they do not look for news when reading a book, or watching a series, or chatting, but instead they perform situations of lesser cognitive engagement such as surfing or chatting with friends. Possibly, one of the screens is used as a source of amusement, while on the other one a task of greater cognitive burden is carried out, as could happen for instance in a situation where the mobile screen has instant messaging active to connect with friends, while the computer is used to watch news. On the other hand, if the piece of news is engaging, the user can search for more news in different channels, which is an effort consuming activity. This situation is represented by the first factor we found, "information in real time." The five factors found driving multiscreen use in a news context, correspond to "information in real time," "comprehension of reality," "social interaction," "leisure" and "habit." They are similar factors to the ones found by Choi, Kim and McMillan (2009) regarding multiscreen use. The search for "instant information" is the only factor that predicts multiscreen use behavior to look for news the day before, while factors such as "information in real time," "social interaction," and "leisure" are relevant when it comes to predict the time of multiscreen use.

In short, technological development has promoted that individuals have multiple devices connected and this reality is deeply modifying media consumption. This research has been carried out whilst other studies are starting to investigate how users relate to multiscreen and what gratifications they get from said behavior. Specifically, it is relevant to know how this multiscreen phenomenon influences individuals when it comes to consume news and what are the factors predicting them.

Media content generators do not live apart from this reality. Therefore, they require research allowing them, from knowledge, to efficiently reach audiences and understand how elements characteristic of the process work, in order to adapt their informative contents to these new multiscreen uses in an optimized manner. 


\section{Research limitations}

One of the limitations of this study is the use of questionnaires to evaluate multiscreen use. We have tried to reduce bias by asking, besides the time of general use of multiscreen, the previous day's use, which we believe is a more reliable evaluation from the memory perspective. Future studies could apply new monitoring methods to achieve more objective measurements. Another research limitation to consider is the age range of the sample population; between 18 and 35 years old. That said, even though there exists academic interest to understand how multiscreen usage is consumed in age ranges superior to 35 years old, the further an individual's position from digital abilities due to age, the less relevant the research results become.

\section{References}

Álvarez, J. M., de Haro, G. \& Picard, R. G. (2018). Digital word of mouth usage in the movie consumption decision process: the role of Mobile-WOM among young adults in Spain. International fournal on Media Management, 20(2), 107-128.

https://www.doi.org/10.1080/14241277.2018.1471606

Armstrong, G. B., Boiarsky, G. A. \& Mares, M. L. (1991). Background television and reading performance. Communications Monographs, 58(3), 235-253. https://www.doi.org/10.1080/03637759109376228

Bailyn, L. (1959). Mass media and children: A study of exposure habits and cognitive effects. Psychological Monographs: General and Applied, 73(1), 1.

https://www.doi.org/10.1037/hoo93739

Bolton N., Parasuraman A., Hoefnagels A., Migchels N., Kabadayi S., Gruber T., Komarova Loureiro Y. \& Solnet D. (2013). Understanding Generation Y and their use of social media: a review and research agenda. Fournal of Service Management, 24(3), 245-267. https://www.doi.org/10.1108/09564231311326987

Bowman, L. L., Levine, L. E., Waite, B. M. \& Gendron, M. (2010). Can students really multitask? An experimental study of instant messaging while reading. Computers \& Education, 54(4), 927-931. https://www.doi.org/10.1016/j.compedu.2009.09.024

Charney, T. \& Greenberg, B. (2001). Uses and gratifications of the Internet. In C. Lin \& D. Atkin (Eds.), Communication technology and society: New media adoption and uses and gratifications (pp. 383-406). Cresskill, NJ: Hampton.

Cheng, Y., Liang, J. \& Leung, L. (2015). Social network service use on mobile devices: An examination of gratifications, civic attitudes and civic engagement in China. New media \& Society, 17(7), 1096-1116. https://www.doi.org/10.1177/1461444814521362

Choi, Y. K., Kim, J. \& McMillan, S. J. (2009). Motivators for the intention to use mobile TV: A comparison of South Korean males and females. International fournal of Advertising, 28(1), 147-167. https://www.doi.org/10.2501/So265048709090477

Cook, T. D. \& Reichardt, Ch. S. (1979). Qualitative and quantitative methods in evaluation research. Beverly Hills, CA: Sage.

de Moragas Spa, M. (1993). Teorías de la comunicación: investigaciones sobre medios en América Latina y Europa. México, Barcelona: Gustavo Gili.

Dias, P. (2016). Motivations for multi-screening: An exploratory study on motivations and gratifications. European fournal of Communication, 31(6), 678-693. https://www.doi.org/10.1177/0267323116674111

Diego, P., Guerrero, E. \& Etayo-Pérez, C. (2014). Televisión conectada en España: contenidos, pantallas y hábitos de visionado. Revista Mediterránea de Comunicación, 5(1), 179-199. https://www.doi.org/10.14198/MEDCOM2014.5.1.10

Dindar, M. \& Akbulut, Y. (2016). Effects of multitasking on retention and topic interest. Learning and Instruction, 41, 94-105.

https://www.doi.org/10.1016/j.learninstruc.2015.10.005 
Fernández, P. E. (2013). Las audiencias en la era digital: interacción y participación en un sistema convergente. Question, 1(40), 68-82.

Flanagin, A. J. \& Metzger, M. J. (2001). Internet use in the contemporary media environment. Human Communication Research, 27(1), 153-181. https://www.doi.org/10.1111/j.14682958.2001.tboo779.x

Flores, I. \& Humanes, M. L. (2014). Hábitos y consumos televisivos de la generación digital desde la perspectiva de los usos y gratificaciones. Estudio de caso en la Universidad Rey Juan Carlos. Revista Mediterránea de Comunicación, 5(1), 137-155. https://www.doi.org/10.14198/MEDCOM2014.5.1.06

Giglietto, F. \& Selva, D. (2014). Second screen and participation: A content analysis on a full season dataset of tweets. Fournal of Communication, 64(2), 260-277. https://www.doi.org/10.1111/jcom.12085

Gil de Zuñiga, H. G. \& Liu, J. H. (2017). Second Screening Politics in the Social Media Sphere: Advancing Research on Dual Screen Use in Political Communication with Evidence from 20 Countries. Fournal of Broadcasting \& Electronic Media, 61(2), 193-219. https://www.doi.org/10.1080/08838151.2017.1309420

Gilbert, D. T., Tafarodi, R. W. \& Malone, P. S. (1993). You can't not believe everything you read. fournal of Personality and Social Psychology, 65(2), 221. https://www.doi.org/10.1037/00223514.65.2.221

Greenberg, B. S. (1974). Gratifications of television viewing and their correlates for British children. The uses of mass communications. Current Perspectives on Gratifications Research, 3, 71-92.

Grellhesl, M. \& Punyanunt, N. M. (2012). Using the uses and gratifications theory to understand gratifications sought through text messaging practices of male and female undergraduate students. Computers in Human Behavior, 28(6), 2175-2181.

https://www.doi.org/10.1016/j.chb.2012.06.024

Hembrooke, H. \& Gay, G. (2003). The laptop and the lecture: The effects of multitasking in learning environments. Fournal of Computing in Higher Education, 15(1), 46-64.

Herzog, H. (1944). What do we really know about daytime serial listeners? In P. F. Lazarsfeld \& F. N. Stanton (Eds.), Radio research, 1942-1943 (pp. 3-33). New York: Duell, Sloan \& Pearce.

Ingunn H. \& Rice, R. E. (2007). Social Connectivity, Multitasking and Social Control: U.S. and Norwegian College Students. Use of Internet and Mobile Phones. Presented in the International Communication Association (ICA) Conference. San Francisco (USA).

James, M. L., Wotring, C. E. \& Forrest, E. J. (1995). An exploratory study of the perceived benefits of electronic bulletin board use and their impact on other communication activities. Fournal of Broadcasting \& Electronic Media, 39(1), 30-50.

https://www.doi.org/10.1080/08838159509364287

Jeong, S. H. \& Hwang, Y. (2016). Media Multitasking Effects on Cognitive vs. Attitudinal Outcomes: A Meta-Analysis. Human Communication Research, ${ }_{42}(4), 599-618$.

https://www.doi.org/10.1111/hcre.12089

Katz, E. (1959). Mass communications research and the study of popular culture: An editorial note on a possible future for this journal. Studies in Public Communication, 2, 1-6.

Katz, E., Blumler, J. G. \& Gurevitch, M. (1973). Uses and gratifications research. The Public Opinion Quarterly, 37(4), 509-523.

Katz, E., Haas, H. \& Gurevitch, M. (1973). On the use of the mass media for important things. American Sociological Review, 38(April), 164-181. https://www.doi.org/10.2307/2094393

Kaye, B. K. \&Johnson, T. J. (2002). Online and in the know: Uses and gratifications of the web for political information. Fournal of Broadcasting \& Electronic Media, 46(1), 54-71. https://www.doi.org/10.1207/s15506878jobem4601_4 
Kononova, A. \& Chiang, Y. H. (2015). Why do we multitask with media? Predictors of media multitasking among Internet users in the United States and Taiwan. Computers in Human Behavior, 50, 31-41. https://www.doi.org/10.1016/j.chb.2015.03.052

Korgaonkar, P. K. \& Wolin, L. D. (1999). A multivariate analysis of web usage. Fournal of Advertising Research, 39, 53-68.

LaRose, R. \& Eastin, M. S. (2004). A social cognitive theory of Internet uses and gratifications: Toward a new model of media attendance. Fournal of Broadcasting \& Electronic Media, 48(3), 358-377. https://www.doi.org/10.1207/S15506878jobem4803_2

Lasswell, H. D. (1948). The structure and function of communication in society. The Communication of Ideas, 37, 215-228.

Leung, L. \& Wei, R. (2000). More than just talk on the move: Uses and gratifications of the cellular phone. Fournalism \& Mass Communication Quarterly, $77(2), 308-320$.

https://www.doi.org/10.1177/107769900007700206

Leung, L. (2007). Unwillingness-to-communicate and college students motives in SMS mobile messaging. Telematics and Informatics, 24(2), 115-129.

https://www.doi.org/10.1016/j.tele.2006.01.002

Leung, L. (2009). User-generated content on the internet: an examination of gratifications, civic engagement and psychological empowerment. New Media \& Society, 11(8), 1327-1347. https://www.doi.org/10.1177/1461444809341264

Levitin, D.J. (1999). Experimental design in psychoacoustic research. In P. R. Cook (Ed.), Music, cognition, and Computerized Sound (pp. 299-328). Cambridge, MA: MIT Press.

Lim, S. \& Shim, H. (2016). Who Multitasks on Smartphones? Smartphone Multitaskers Motivations and Personality Traits'. Cyberpsychology Behavior and Social Networking, 19(3), 223-227. https://www.doi.org/10.1089/cyber.2015.0225

Lin, J. S. \& Cho, C. H. (2010). Antecedents and consequences of cross-media usage: A study of a TV program's official web site. Fournal of Broadcasting \& Electronic Media, 54(2), 316336. https://www.doi.org/10.1080/08838151003737998

Lin, T. T. (2013). Convergence and regulation of multi-screen television: The Singapore experience. Telecommunications Policy, 37(8), 673-685.

https://www.doi.org/10.1016/j.telpol.2013.04.011

McIlwraith, R. D. (1998). I'm addicted to television: The personality, imagination, and TV watching patterns of self-identified TV addicts. Fournal of Broadcasting \& Electronic Media, $42(3), 371-386$. https://www.doi.org/10.1080/08838159809364456

McQuail, D. (1979). The uses and gratification approach: Past, troubles, and future. Massacommunicatie, $7(3), 73-89$.

McQuail, D., Blumler, J. G. \& Brown, J. R. (1972). The television audience: A revised perspective. In D. McQuail (Ed.), Sociology of mass communications (pp. 135-165). Harmondsworth: Penguin.

Meyer, D. E. \& Kieras, D. E. (1997). A computational theory of executive cognitive processes and multiple-task performance: Part 2. Accounts of psychological refractory-period phenomena. Psychological Revier, 104(4), 749. https://www.doi.org/10.1037/0033295X.104.4.749

Niño, J. I. \& Fernández, B. (2015). Comunicación, Salud y tecnología: mHealth. Revista de comunicación y salud, 5, 149-158.

https://www.doi.org/10.35669/revistadecomunicacionysalud.2015.5(1).149-158

Palmgreen, P. (1984). Uses and gratifications: A theoretical perspective. Annals of the International Communication Association, 8(1), 20-55.

https://www.doi.org/10.1080/23808985.1984.11678570

Papacharissi, Z. \& Rubin, A. M. (2000). Predictors of Internet use. Fournal of Broadcasting \& Electronic Media, 44(2), 175-196. https://www.doi.org/10.1207/s15506878jobem4402_2 
Pashler, H., Kang, S. H. \& Ip, R. Y. (2013). Does multitasking impair studying? Depends on timing. Applied Cognitive Psychology, 27(5), 593-599. https://www.doi.org/10.1002/acp.2919

Pedreira, M. C. C. \& de Casas Moreno, P. (2016). La competencia mediática como forma de análisis de la realidad transmitida. Revista de la Asociación Española de Investigación de la Comunicación, 3(6), 77-83. https://www.doi.org/10.24137/raeic.3.6.10

Perse, E. M. \& Rubin, A. M. (1988). Audience activity and satisfaction with favorite television soap opera. Fournalism Quarterly, 65(2), 368-375.

https://www.doi.org/10.1177/107769908806500216

Prensky, M. (2001). Digital natives, digital immigrants part 1. On the Horizon, 9(5), 1-6.

Quan, A. \& Young, A. L. (2010). Uses and Gratifications of Social Media: A Comparison of Facebook and Instant Messaging. Bulletin of Science, Technology \& Society, 30(5), 350-361. https://www.doi.org/10.1177/0270467610380009

Rainie, L. \& Wellman, B. (2012): Networked. The New Social Operating System. Cambridge, MA: The MIT Press.

Rideout, V. J., Foehr, U. G. \& Roberts, D. F. (2010). Generation M²: Media in the Lives of 8- to 18-Year-Olds. A Kaiser Family Foundation Study. Retrieved from https://files.eric.ed.gov/fulltext/ED527859.pdf

Rosen, L. D., Lim, A. F., Carrier, L. M. \& Cheever, N. A. (2011). An empirical examination of the educational impact of text message-induced task switching in the classroom: Educational implications and strategies to enhance learning. Psicología Educativa, 17(2), 163-177. https://www.doi.org/10.5093/ed2011v17n2a4

Rubin, A. M. (2009). Uses and gratifications: An evolving perspective on media effects. In R. L. Nabi \& M. B. Oliver (Eds.), The Sage handbook of media processes and effects (pp. 147-159). Thousand Oaks, CA: Sage.

Salvucci, D. D. \& Taatgen, N. A. (2008). Threaded cognition: an integrated theory of concurrent multitasking. Psychological Review, 115(1), 101. https://www.doi.org/10.1037/0033295X.115.1.101

Schramm, W. L., Parker, E. B. \& Lyle, J. (1961). Television in the Lives of Children. Stanford: Stanford University Press.

Shade, D. D., Kornfield, S. \& Oliver, M. B. (2015). The uses and gratifications of media migration: Investigating the activities, motivations, and predictors of migration behaviors originating in entertainment television. Fournal of Broadcasting \& Electronic Media, 59(2), 318-341. https://www.doi.org/10.1080/08838151.2015.1029121

Sundar, S. S. \& Limperos, A. M. (2013). Uses and grats 2.0: New gratifications for new media. Fournal of Broadcasting \& Electronic Media, 57, 504-525.

https://www.doi.org/10.1080/08838151.2013.845827

Tran, P. D. (2012). The effects of online communication while reading on content knowledge, reading comprehension, and long-term memory. California State University, Los Angeles. ProQuest Dissertations and Theses, 137. Retrieved from http://eduproxy.tclibrary.org/?url=/docview/1014403621?accountid=14258. (1014403621)

Vaccari, C. \& Valeriani, A. (2018). Dual screening, public service broadcasting, and political participation in eight western democracies. The International fournal of Press/Politics, 23(3), 367-388. https://www.doi.org/10.1177/1940161218779170

Wang, Z., Busemeyer, J. R. \& Lang, A. (2006). Grazing or staying tuned: A dynamic stochastic model of channel changing behavior. In R. Sun \& N. Miyake (Eds.), The $28^{\text {th }}$ Annual Conference of the Cognitive Science Society (pp. 870-875). Mahwah, NJ: Erlbaum.

Wang Z. \& Tchernev J. M. (2012). The "Myth" of Media Multitasking: Reciprocal Dynamics of Media Multitasking, Personal Needs, and Gratifications. Fournal of Communication, 62(3), 493-513. https://www.doi.org/10.1111/j.1460-2466.2012.01641.x

Yuste, B. (2015). Las nuevas formas de consumir información de los jóvenes. Revista de estudios de juventud, 108, 179-191. 